\title{
Susceptibility of Chinese Hemlock (Tsuga chinensis) to Injury from Autumn Horticultural Oil Applications
}

\author{
Richard W. Harper and Richard S. Cowles
}

\begin{abstract}
Chinese hemlock (Tsuga chinensis) has been suggested as a possible replacement in landscape plantings for eastern hemlocks (T. canadensis), which are being lost due to infestations of hemlock woolly adelgid (Adelges tsugae). Chinese hemlock is highly resistant to hemlock woolly adelgid, but is a host for elongate hemlock scale (Fiorinia externa). Horticultural oil is a popular insecticide commonly used by professionals to manage various insect and mite pests of hemlock in landscapes, including hemlock woolly adelgid, spruce spider mite, and armored scales. In tests, horticultural oil applied in two separate autumn sprays was not phytotoxic to Chinese hemlocks. Therefore, $1 \%$ or $2 \%$ horticultural oil may be used to maintain Chinese hemlocks in landscape plantings.

Key Words. Adelgid; Chinese Hemlock; Fiorinia externa; Horticultural Oil; Tsuga chinensis.
\end{abstract}

Eastern hemlock [Tsuga canadensis (L.) Carrière)] is highly valued for planting in landscapes due to its evergreen, dense foliage, graceful, pyramidal growth form, and tolerance of moist soils. T. canadensis is very shade tolerant, which allows it to retain needles on several years of growth and makes it amenable to shearing for use in landscape hedges. The threat of losing eastern hemlock in landscape plantings due to hemlock woolly adelgid (HWA) (Adelges tsugae Annand), has led to investigations of replacement species of hemlocks. The relationship between hemlock species and their associated strains of adelgids is complex. Eastern and Carolina hemlocks (Tsuga caroliniana Engelmann) quickly decline in health and die when fed upon by adelgids, to which they are not adapted. Other species of hemlock found in western North America and Asia have coevolved with or exhibit forms of resistance to hemlock woolly adelgids, and are rarely damaged by their feeding (Montgomery et al. 2009). The strain of HWA found in the eastern United States is believed to have originated from Japan (Havill and Montgomery 2008), and several studies point to Chinese hemlock [Tsuga chinensis (Franch.) E. Pritz] as highly resistant to this strain of HWA (Del Tredici and Kitajima 2004; Hoover et al. 2009; Montgomery et al. 2009; Weston and Harper 2009). Additionally, T. chinensis exhibits many of the same growing characteristics as $T$. canadensis - it is fast growing, shade tolerant, has a graceful form, and is fully hardy in USDA Zone 6 (Del Tredici and kitajima 2004). Besides being highly resistant to A. tsugae, T. chinensis may also be somewhat less susceptible to spider mites, presumably $O$. ununguis (Jacobi), than T. canadensis (Del Tredici and Kitajima 2004).

It would be premature to recommend replacing $T$. canadensis with $T$. chinensis if Chinese hemlocks are too susceptible to other pests. Based on observations of a planting of eastern and Chinese hemlocks established at Lasdon Park and Arbore- tum (Katonah, New York) since 2003, both species appear to be suitable hosts for the elongate hemlock scale (EHS) (Fiorinia externa Ferris). In 2008, populations of EHS were found on $73 \%$ and $35 \%$ of specimens of T. canadensis and T. chinensis, respectively (Weston and Harper, 2009). Elongate hemlock scale is an armored scale (Family: Diaspididae) first discovered in Queens, New York, in 1908 and formally described in 1942. It is known to occur on several native and commonly planted ornamental trees and shrubs, including yew (Taxus spp.), Douglas-fir (Pseudotsuga menziesii), true firs (Abies spp.), spruce (Picea spp.) and native eastern and Carolina hemlocks (McClure and Fergione 1977). Johnson and Lyon (1994) described EHS as a "destructive pest of established landscape trees and hedges," but in contrast noted it infesting "very few" stands of native hemlocks; the range was reported to include southern New England (Massachusetts, Connecticut, U.S.), other northeastern states such as New Jersey, Maryland, and Pennsylvania, and as far west as Ohio. Elongate hemlock scale has more recently been recognized as a pest of forest as well as landscape trees (McClure 2002) and within the past five years has caused significant decline of forested stands in New England-sufficient to warrant salvage harvest of the dying trees (Kyle Lombard, NH Forest Health Program Coordinator; David Irvin, Connecticut, U.S., DEEP Forester, pers. comm.).

After a newly hatched scale crawls to, or is transported by wind to, a suitable host plant, it inserts a stylet into the underside of the needle, removing plant fluids from the mesophyll cells. As scale populations build-especially on hemlocks already stressed by drought or HWA infestation-foliage may exhibit chlorosis, followed by needle drop, branch dieback, and whole-plant death within 10 years of initial infestation (McClure 2002). Although potentially serious, EHS infesta- 
tions may be successfully managed in ornamental landscape plantings with commercial insecticides. Insecticides used for managing insect and mite pests of hemlocks include systemic insecticides (imidacloprid or dinotefuran), contact insecticides, insect growth regulators, and horticultural oil (Cowles et al. 2006; Raupp et al. 2008; Cowles 2009; Cowles and Cheah 2002a; Cowles and Cheah 2002b). Effective materials for targeting EHS include autumn or early spring application of dinotefuran as a bark spray or soil drench (Cowles 2010), interruption of development with pyriproxyfen, an insect growth regulator (Raupp et al. 2008), or application of horticultural oil (Raupp et al. 2008). Horticultural oil is especially important because it can effectively suppress hemlock woolly adelgid, armored scales, spruce spider mites, and hemlock rust mites, while having limited impact on beneficial predators and parasites due to its non-residual properties (Davidson et al. 1990).

The potential phytotoxic response of ornamental trees and shrubs to modern summer-type paraffinic horticultural oils is both unpredictable (from a phylogenetic perspective) and relatively uncommon (Baxendale and Johnson 1988; Davidson et al. 1990). In their severe test for phytotoxicity under drought conditions, Davidson et al. (1990) repeatedly sprayed 52 species or cultivars with $2 \%$ Sunspray 6E PLUS. Of these, there were 13 representative conifers, and changes in plant appearance were observed only based upon disturbance of glaucous waxes (such as Colorado blue spruce, Picea pungens) in two species, which may not be injurious to the plant, and highly variable injury to $P$. abies, which was attributed to possible excessive spray application. A slight yellowing on some leaves was noted for weeping hemlock ( $T$. canadensis 'Sargentii'), but not the species form of $T$. canadensis. In other studies of conifers Douglas-fir was found to be sensitive to horticultural oil, as demonstrated by reproducible chlorosis among treated trees (Varela et al. 1996), whereas true firs (Abies spp.) typically exhibit chlorosis of new growth if sprayed with oil during shoot elongation (Cowles, pers. obs.). The replicated plantings of T. canadensis and T. chinensis at Lasdon Arboretum provided an opportunity to investigate and compare phytotoxic response to horticultural oil in a replicated trial using 15 individual specimens of each species.

\section{MATERIALS AND METHODS}

\section{Research Site}

On September 30, 2003, a total of 18 specimens of T. chinensis were established in three different experimental plots, among six other species of hemlock (T. canadensis, T. caroliniana, T. heterophylla, T. mertensiana, T. sieboldii, T. diversifolia) in randomized plots at Lasdon Arboretum (Weston and Harper 2009). Plots were approximately $12 \mathrm{~m} \times 14 \mathrm{~m}$, ranging from fullpartial sun (Front Gate and Magnolia Garden Plots) to full shade (Hemlock Hedge Plot) established within fenced perimeters to protect trees from deer herbivory. Soils where the hemlock plantings were established were clay-based and had previously had significant amounts of organic matter incorporated into them through annual mulching with $5-10 \mathrm{~cm}$ depth of wood chips, since their time of establishment. High levels of earthworm activity make maintaining an adequate mulch cover difficult. Overall conditions during the summer prior to oil application were warmer and drier than normal, as indicated by averages from

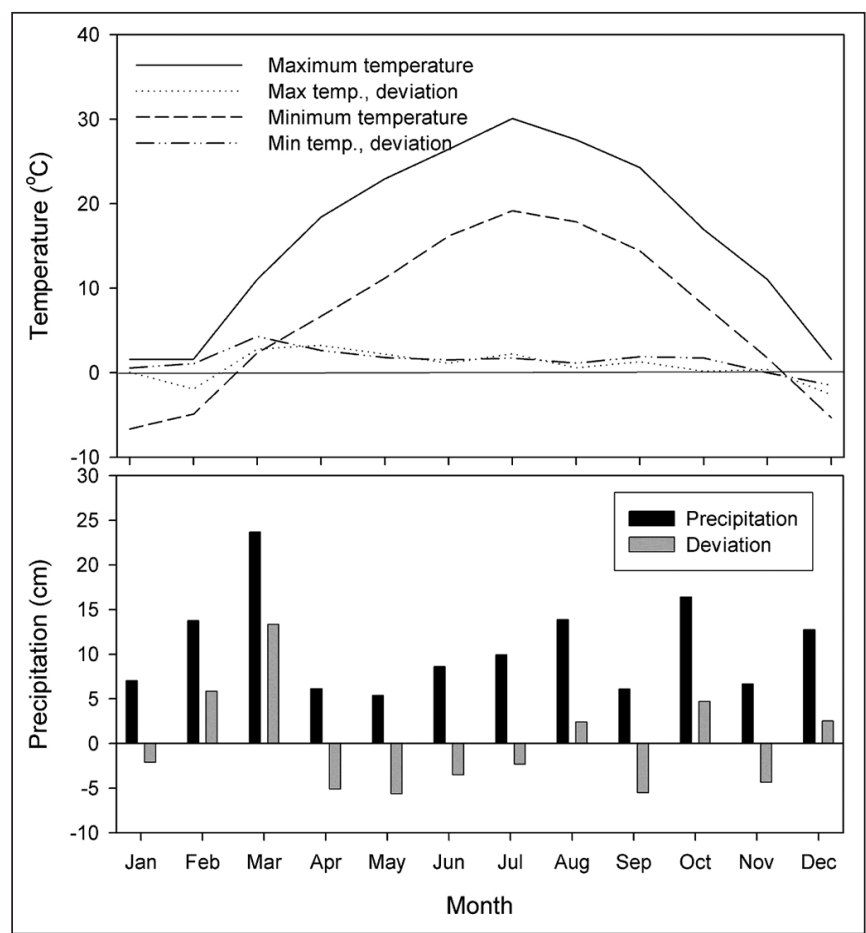

Figure 1. Monthly average temperature maximum and minimum data, and precipitation data for Yorktown, New York, U.S., for 2010, are compared with their deviations from the 30-year average (including 2010).

the previous 30 years at a nearby weather station (Yorktown, NY). Temperature and precipitation monthly averages and their deviations from 30-year averages are presented in Figure 1.

\section{Treatment Protocols}

Five of the largest $T$. chinensis (3.1-4.6 m height, mean of $3.7 \mathrm{~m}$ ) and an equal number of similarly sized T. canadensis specimens $(2.6-5.1 \mathrm{~m}$ height, mean of $3.7 \mathrm{~m})$ were identified in each of the three plots, for a total of 30 experimental units. Six individual branches on each study tree were marked with color-coded flagging tape to identify the treatment combinations in a 3 dosages $\times 2$ spray timings factorial design experiment. Treatments were: 1) $1 \%$ horticultural oil application, 2) $2 \%$ horticultural oil application, and 3) untreated check. The first treatment was administered on September 29 and the second spray was applied on November 10, 2010.

Lesco Horticulture Oil Insecticide (98.8\% mineral oil) was applied with a 7.6 L hand-held pump (garden) sprayer to the point of runoff. The first application timing was selected to be optimal for HWA management. Late September-early October is a window of treatment opportunity to contact sistens (the overwintering generation) before they resume development and cover themselves with wool. If there was a significant acute phytotoxic response, such as needle loss, then it might occur within one to four weeks after spraying. Later spray timings can be of concern as horticultural oil may affect the tree physiology or leaf cuticle integrity for some weeks (Hodgkinson et al. 2002), or lead to injury that may occur when sprays are followed by freezing temperatures, possibly resulting in 
excessive winter desiccation and needle loss. However, commercial arborists often extend their oil treatments well into October-November in Westchester County and the Lower Hudson Valley due to logistical reasons and seasonal temperature/ weather variation. Therefore, a second application was administered in November to investigate possible injury that might appear by the following spring related to a late spray timing.

A simple 0-5 rating system was used to evaluate possible injury to foliage, based upon expected symptoms from oil phytotoxicity. Branches chosen for treatment were examined, and the foliage condition was assigned a rating: 5 denoted a "perfect" appearance (i.e., abundant lush, green leaf cover free from chlorosis, necrosis), 4 indicated a very small degree of imperfection (i.e., one or two chlorotic or brown needles on a branch), 3 indicated significant aesthetic compromise (i.e., many chlorotic/brown needles on a branch), 2 indicated widespread needle loss, 1 represented a nearly dead branch (minimal green foliage, growth), and 0 indicating complete necrosis. Pre-treatment appearance ratings were performed on August 18 and September 24, 2010, based on the trees' overall foliage rating. Foliage quality ratings from the September and November treatments with horticultural oil were recorded on October 29 and December 9, 2010, respectively, 30 days after each spray treatment.

Informal examination of all treated hemlocks took place on three occasions in the spring/summer months of 2011 (March, May, and July) during regular plot maintenance. It was readily apparent that there were no notable changes/ differences in foliage quality (color, needle loss, necrosis) when compared to other portions of the trees that had been treated with horticultural oil the previous autumn. Armored scales and other arthropod populations (e.g., HWA, spruce spider mites) were not sampled due to limited availability of labor.

\section{Data Analysis}

Foliage quality ratings from both 30-day post-treatment dates were compared in one analysis of variance. Because there were potential differences in tree condition related to their planting site, the experiment was treated as a $3 \times 2 \times 3$ factorial design experiment, where the oil treatment ( 3 levels) could interact with date of application (2 levels) and the site (3 levels), with five single tree replicates per site. Data were analyzed using Statistix 9 software (Analytical Software, Tallahassee, Florida, U.S.).

\section{RESULTS AND DISCUSSION}

Highly statistically significant differences in foliage quality ratings were found based on species, time of evaluation, site, and each of these factors' two-way interactions (Table 1) ( $\mathrm{F}>4.96$; df $=1$ or 2,$168 ; P<0.01)$; data did not require transformation to fulfill the assumptions for the analysis of variance. However, there was no evidence that horticultural oil sprays were associated with any symptomatic injury to foliage, as the oil treatment's main effect and its interactions were all statistically insignificant $(\mathrm{F}<1.51, \mathrm{df}=2$ or 4,$144 ; P>0.2)$. Indeed, the overall foliage quality ratings were very high for $\mathrm{T}$. chinensis at all ratings and sites (averaging between 3.9 and 5, grand mean of 4.4) (Figure 2). Ratings were more variable for T. canadensis (grand mean of 4.1), but appearances were influenced by site conditions. In follow-up informal observations of the treated specimens made

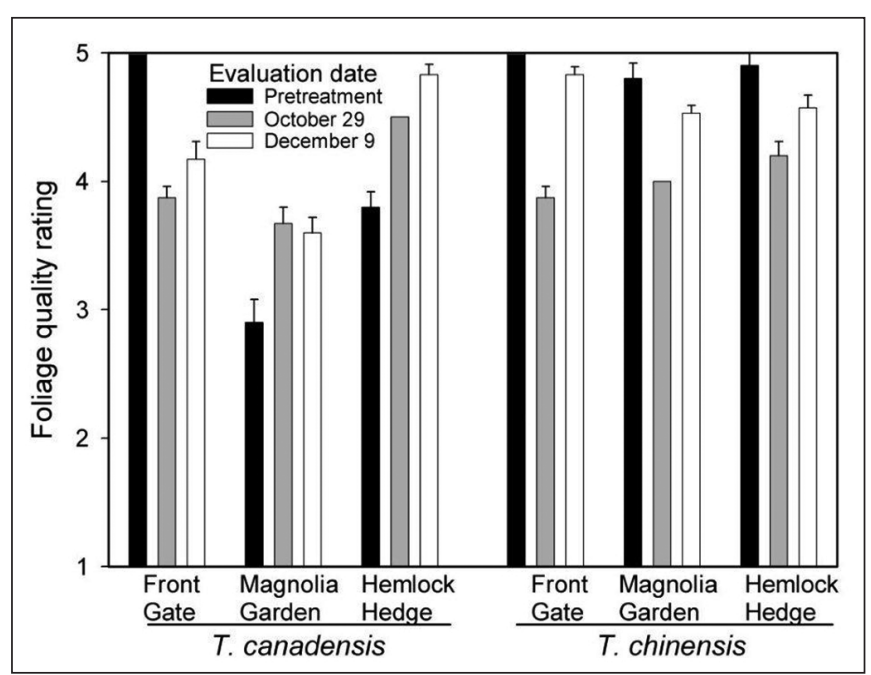

Figure 2. Foliage quality ratings (mean $\pm \mathrm{SE}$ ) of eastern and Chinese hemlocks from three replicated common garden plantings at Lasdon Arboretum. Quality ratings were on a subjective 0-5 scale (dead-dark green), and were recorded on October 29 and December 9, 2010 (date effect). Foliage ratings from eastern and Chinese hemlocks were averaged over the oil application dosages, for which there were no significant differences. Each main effect mean for date, site, and species significantly differed (Tukey HSD test, $P<0.05$ ). Each bar represents five trees.

in the spring and summer of 2011, there were no delayed phytotoxic effects observed on either species in any oil treatment.

Paraffinic horticultural oils are believed to have the potential to cause injury to plants through two mechanisms (Hodgkinson et al. 2002). Acute toxicity is characterized by necrotic spotting on leaves, sudden abscission of green leaves, and injury to meristematic tissue, which results from penetration of oil and/or formulation emulsifiers into the leaves where they dissolve and disrupt cell membranes. The oil used in this study, Lesco Horticultural Oil, has only $1.2 \%$ formulation by weight of emulsifiers, $0 \%-20 \%$ percent heavy paraffinic petroleum, and a relatively low $50 \%$ distillation point of $212^{\circ} \mathrm{C}$, all of which minimize the likelihood of acute toxicity to plants while maintaining pesticidal activity. Chronic toxicity results from persistence of oils on leaf surfaces and temporary interference with basic biological processes in plants, such as transpiration and respiration. Oil-caused stress added to other existing stressors can cause failure of function in the plant tissues, characterized by leaf yellowing or poor growth. In spite of this trial being carried out in mildly droughtstressed conditions, neither species of hemlock was adversely affected by the application of oil at $1 \%$ or $2 \%$ concentrations.

In general, color ratings were higher for T. chinensis than for T. canadensis, with the exception of the T. canadensis in the Hemlock Hedge Plot, which featured excellent color where the ratings of 4.5 were equivalent for the two species. A number of underlying factors may have been responsible: this planting site is forested and offers a generally cooler, well-shaded environment similar to where hemlocks grow naturally. In comparison, the Tsuga spp. in the other two plots (i.e., Front Gate and Magnolia Garden, average ratings of 4.2 and 3.6, respectively) are shaded only from early to mid-afternoon through early to mid-morning (depending on the angle of the sun) and experience significantly more sunlight with associated hotter and drier conditions. Informal obser- 
vations found higher HWA and EHS populations on T. canadensis in these plots compared to the shaded Hemlock Hedge planting, which may also be contributing to the lower aesthetic values associated with some of these trees. The hotter, drier, sunnier conditions may stress $T$. canadensis predisposing them to greater injury from insect pests (Mattson and Haack 1987) or otherwise provide conditions more favorable for pest development. An alternative hypothesis is that the hemlocks surrounded and partially shaded by hardwoods may benefit from generalist predators from the surrounding arboreal vegetation (Hanks and Denno 1993).

\section{CONCLUSIONS}

Currently, 17 of 18 (94.4\%) T. chinensis specimens have survived since their initial installation at Lasdon Park and Arboretum in Northern Westchester County on September 30, 2003. Observations since establishment find a consistent growth and excellent visual quality (i.e., lush green foliage) on a tree that somewhat resembles the form and appearance of T. canadensis. T. chinensis is shade tolerant, features a relatively rapid growth rate, and is resistant to HWA (Del Tredici and Kitajima 2004; Hoover et al. 2009; Montgomery et al. 2009; Weston and Harper 2009). These established traits continue to strengthen the case that this tree would make a suitable replacement for $T$. canadensis in northeastern landscapes. Along with resistance to HWA, there are some indications that it could be less susceptible to spruce spider mites (Del Tredici and Kitajima 2004) and possibly elongate hemlock scale (Weston and Harper 2009), relative to eastern hemlock. The current study suggests, should Chinese hemlock require treatment for any pest that can be managed with horticultural oil, the species tolerates a $1 \%$ or $2 \%$ horticultural oil application in the autumn.

Acknowledgments. Special thanks to the Watershed Agricultural Council for providing a financial contribution towards this research, and to Lora Schwartzberg, Jason Dampier, Jessica Rennells and Jerry Giordano for their assistance associated with the collection/interpretation of field data, weather records, administration of horticultural oil and general plot maintenance. We are also grateful to Ted Kozlowski and the staff at Lasdon Park and Arboretum, and the Westchester County Parks, Recreation and Conservation department for the space to conduct this research and access to on-site resources. Finally, we wish to acknowledge the ongoing support of both the Cornell University Cooperative Extension of Westchester County, and Paul A. Weston, Ph.D., for his invaluable contribution in the setup and establishment of the original hemlock spp. research planting on September 30, 2003.

\section{LITERATURE CITED}

Baxendale, R.W., and W.T. Johnson. 1988. Evaluation of summer oil spray on amenity plants. Journal of Arboriculture 14(9):220-225.

Cowles, R.S. 2009. Optimizing dosage and preventing leaching of imidacloprid for management of hemlock woolly adelgid in forests. Forest Ecology and Management 257:1026-1033.

Cowles, R.S. 2010. Optimizing a basal bark spray of dinotefuran to manage armored scales (Hemiptera: Diaspididae) in Christmas tree plantations. Journal of Economic Entomology 103:1735-1743.

Cowles, R.S., and C.A.S.-J. Cheah. 2002a. Systemic control of hemlock woolly adelgid, 1999. Arthropod Management Tests 27:G47.

Cowles, R.S., and C.A.S.-J. Cheah. 2002b. Foliar sprays for control of hemlock woolly adelgid, 2001. Arthropod Management Tests 27:G48.
Cowles, R.S., M.E. Montgomery, and C.A.S.-J. Cheah. 2006. Activity and residues of imidacloprid applied to soil and tree trunks to control hemlock woolly adelgid (Hemiptera: Adelgidae) in forests. Journal of Economic Entomology 99:1258-1267.

Davidson, J.A., S.A. Gill, and M.J. Raupp. 1990. Foliar and growth effects of repetitive summer horticultural oil sprays on trees and shrubs under drought stress. Journal of Arboriculture 16:77-81.

Del Tredici, P., and A. Kitajima. 2004. Introduction and cultivation of Chinese hemlock (Tsuga chinensis) and its resistance to hemlock woolly adelgid (Adelges tsugae). Journal of Arboriculture 20:282-287.

Hanks, L.M., and R.F. Denno. 1993. Natural enemies and plant water relations influence the distribution of an armored scale insect. Ecology 74:1081-1091.

Havill, N.P., and M.E. Montgomery. 2008. The role of arboreta in studying the evolution of host resistance to the hemlock woolly adelgid. Arnoldia 65:2-9.

Hodgkinson, M.C., D. Johnson, and G. Smith. 2002. Causes of phytotoxicity induced by petroleum derived spray oil, pp. 170-178. In: A. Beattie, D. Watson, M. Stevens, D. Rae, and R. Spooner-Hart (Eds.). Spray Oils Beyond 2000, Sustainable Pest and Disease Management. Univ. Western Sydney. 627 pp.

Hoover, B.K., R.M. Bates, J.C. Sellmer, and G.A. Hoover. 2009. Challenging Chinese hemlock (Tsuga chinensis) with hemlock woolly adelgid (Adelges tsugae) ovisacs. Arboriculture \& Urban Forestry 35(1):1-4.

Johnson, W.T., and H.H. Lyon. 1994. Insects That Feed on Trees and Shrubs. 2nd Ed. Rev. Cornell University Press, Ithaca, New York, U.S.

Mattson, W.J., and R.A. Haack. 1987. The role of drought in outbreaks of plant-feeding insects. Bio-Science 37(2):110-118.

McClure, M.S. 2002. Elongate Hemlock Scale. USDA Forest Service Pest Alert. Acessed 03/22/2011. <http://na.fs.fed.us/spfo/pubs/pest_ al/ehscale/ehscale.htm>

McClure, M.S., and M.B. Fergione. 1977. Fiorinia externa and Tsugaspidiotus tsugae (Homoptera: Diaspididae): Distribution, abundance, and new hosts of two destructive scale insects of eastern hemlock in Connecticut. Environmental Entomology 6:807-811.

Montgomery, M.E., S.E. Bentz, and R.T. Olsen. 2009. Evaluation of hemlock (Tsuga) species and hybrids for resistance to Adelges tsugae (Hemiptera: Adelgidae) using artificial infestation. Journal of Economic Entomology 102:1247-1254.

Raupp, M., R. Ahern, B. Onken, R. Reardon, S. Bealmear, J. Doccola, P. Wolfe II, and P. Becker. 2008. Efficacy of foliar applications, trunk injections, and soil drenches in reducing populations of elongate hemlock scale on eastern hemlock. Arboriculture \& Urban Forestry 34:325-329.

Varela, L.G., R.S. Cowles, and D. Donaldson. 1996. Spring insecticide treatments control adelgids on Douglas-fir. California Agriculture 50(5):34-37.

Weston, P.A., and R.W. Harper. 2009. Potential of Tsuga spp. from western North America and Asia as replacements for eastern hemlock (Tsuga canadensis). Arboriculture \& Urban Forestry 35:5-9. 
Richard W. Harper (corresponding author)

Department of Environmental Conservation

University of Massachusetts

160 Holdsworth Way

Amherst, Massachusetts 01003, U.S.

rharper@eco.umass.edu

Richard S. Cowles

Connecticut Agricultural Experiment Station

Valley Laboratory

Windsor, Connecticut 06095, U. S.

Richard.Cowles@ct.gov

Résumé. L'emploi de pruches de Chine (Tsuga chinensis) a été suggéré en tant qu'espèce possible de remplacement pour les pruches du Canada (Tsuga canadensis) qui ont été perdues au sein des aménagements suite aux dommages causés par le puceron lanigère de la pruche (Adelges tsugae). La pruche de Chine est hautement résistante au puceron lanigère de la pruche, mais elle est un hôte pour la cochenille allongée de la pruche (Fiorinia externa). L'huile horticole est un insecticide populaire communément employé par les professionnels afin de contrôler de nombreux insectes et acariens chez les pruches au sein des aménagements, incluant le puceron lanigère de la pruche, la tétranyque de l'épinette et les cochenilles. Dans les essais, l'huile horticole appliquée par vaporisation durant deux automnes distincts n'était pas phytotoxique pour la pruche de Chine. Partant de là, de l'huile horticole à $1 \%$ ou $2 \%$ pourrait être utilisée pour assurer le maintien des pruches de Chine dans les aménagements.

Zusammenfassung. Die Chinesische Hemlocktanne (Tsuga chinensis) wird bei Pflanzungen als möglicher Ersatz für die Kanadische Hemlocktanne (T. canadensis) vorgeschlagen, weil diese aufgrund des Befalls mit der Hemlock-Wollschildlaus (Adelges tsugae) zunehmend ausfällt. Die Chinesische Hemlocktanne ist hochgradig resistent gegen die Wollschildlaus, aber sie ist ein Wirt für die lange Hemlockschildlaus . Pflanzenöl ist ein populäres Insektizid, welches oft von Profis eingesetzt wird, um verschiedene Insekten und Milben auf Hemlocktannen zu kontrollieren, einschließlich der Hemlock-Wollschildlaus, der Fichtenspinnmilbe und anderer Schildläuse. In Testreihen erwies sich das Pflanzenöl in zwei verschiedenen Herbst-Sprays als nicht-toxisch für die Chinesische Hemlocktanne. Daher unsere Enpfehlung zur Verwendung von 1\% oder 2\% Pflanzenöl bei der Pflanzung von Chinesischer Hemlocktanne in der Landschaft.

Resumen. El abeto chino (Tsuga chinensis) ha sido sugerido como un posible remplazo en plantaciones para abetos del este (T. canadensis), el cual se está perdiendo debido a infestaciones por el aldégido (Adelges tsugae). El abeto chino es altamente resistente al aldégido, pero es hospedero de la escama (Fiorinia externa). El aceite horticultural es un insecticida popular comúnmente usado por los profesionales para manejar varios insectos y plagas de ácaros de abetos, incluyendo el aldégido, arañas y escamas. En pruebas, el aceite horticultural aplicado en dos aspersiones separadas en otoño no fue fitotóxico para los abetos chinos. En consecuencia, $1 \%$ o $2 \%$ del aceite horticultural puede ser usado para mantener los abetos chinos en plantaciones urbanas. 